\title{
IODP workshop: Core-Log Seismic Investigation at Sea - Integrating legacy data to address outstanding research questions in the Nankai Trough Seismogenic Zone Experiment
}

\author{
Anna Cerchiari $^{1}$, Rina Fukuchi ${ }^{2}$, Baiyuan Gao ${ }^{3}$, Kan-Hsi Hsiung ${ }^{4}$, Dominik Jaeger ${ }^{5}$, Shunya Kaneki ${ }^{6}$, \\ Jonas Keller ${ }^{5}$, Gaku Kimura ${ }^{7}$, Szu-Ting Kuo ${ }^{8}$, Gaël Lymer ${ }^{9}$, Tatiana Maison ${ }^{10}$, Ginta Motohashi ${ }^{11}$, \\ Christine Regalla $^{12}$, Drake Singleton ${ }^{13}$, and Suguru Yabe ${ }^{14}$ \\ ${ }^{1}$ Department of Chemical and Geological Sciences, University of Modena and Reggio Emilia, \\ Modena, 41125, Italy \\ ${ }^{2}$ Atmosphere and Ocean Research Institute, The University of Tokyo, Chiba, 277-8564, Japan \\ ${ }^{3}$ Department of Geological Sciences, Institute for Geophysics, The University of Texas at Austin, \\ Austin, TX 78712, USA \\ ${ }^{4}$ Research and Development Center for Ocean Drilling Science, Japan Agency for Marine-Earth Science and \\ Technology, Yokohama, 236-0001, Japan \\ ${ }^{5}$ Department of Geology, University of Innsbruck, Innsbruck, 6020, Austria \\ ${ }^{6}$ Department of Earth and Space Sciences, Osaka University, Osaka, 560-0043, Japan \\ ${ }^{7}$ Department of Marine Environment and Resources, Tokyo University of Marine Science and Technology, \\ Tokyo, 108-8477, Japan \\ ${ }^{8}$ Department of Geology and Geophysics, Texas A\&M University, TX 77843, USA \\ ${ }^{9}$ Earth Sciences Research Group, University of Birmingham, Birmingham, B15 2TT, UK \\ ${ }^{10}$ UMR 2018.C100 Basins-Reservoirs-Resources (B2R), UniLaSalle, UPJV, Beauvais, 60026, France \\ ${ }^{11}$ Graduate School of Life and Environmental Sciences, University of Tsukuba, Ibaraki, 305-0006, Japan \\ ${ }^{12}$ Department of Earth and Environment, Boston University, Boston, MA 02215, USA \\ ${ }^{13}$ Department of Geological Sciences, San Diego State University, San Diego, CA 92182, USA \\ ${ }^{14}$ Department of Solid Earth Geochemistry, Japan Agency for Marine-Earth Science and Technology, \\ Kanagawa, 237-0061, Japan \\ Correspondence: Gaël Lymer (g.lymer@bham.ac.uk)
}

Received: 15 May 2018 - Revised: 21 August 2018 - Accepted: 10 September 2018 - Published: 22 October 2018

Abstract. The first International Ocean Discovery Program (IODP) Core-Log-Seismic Integration at Sea (CLSI@Sea) workshop, held in January-February 2018, brought together an international, multidisciplinary team of 14 early-career scientists and a group of scientific mentors specialized in subduction zone processes at the Nankai Trough, one of the Earth's most active plate-subduction zones located off the southwestern coast of Japan. The goal of the workshop was to leverage existing core, log, and seismic data previously acquired during the IODP's Nankai Trough Seismogenic Zone Experiment (NanTroSEIZE), to address the role of the deformation front of the Nankai accretionary prism in tsunamigenic earthquakes and slow slip in the shallow portion of the subduction interface. The CLSI@Sea workshop was organized onboard the D/V Chikyu concurrently with IODP Expedition 380, allowing workshop participants to interact with expedition scientists installing a longterm borehole monitoring system (LTBMS) at a site where the workshop's research was focused. Sedimentary cores from across the deformation front were brought onboard Chikyu, where they were made available for new description, sampling, and analysis. Logging data, drilling parameters, and seismic data were also available for 
investigation by workshop participants, who were granted access to Chikyu laboratory facilities and software to perform analyses at sea.

Multi-thematic presentations facilitated knowledge transfer between the participants across field areas, and highlighted the value of multi-disciplinary collaboration that integrates processes across different spatiotemporal scales. The workshop resulted in the synthesis of existing geophysical, geologic, and geochemical data spanning IODP Sites C0006, C0007, C0011 and C0012 in the NanTroSEIZE area, the identification of key outstanding research questions in the field of shallow subduction zone seismogenesis, and fostered collaborative and individual research plans integrating new data analysis techniques and multidisciplinary approaches.

1

Subduction zones account for $90 \%$ of global seismic moment release and generate damaging earthquakes and tsunamis with potentially disastrous effects on heavily populated coastal areas (e.g., Lay et al., 2005; Moreno et al., 2010; Simons et al., 2011). Seismologic, geodetic, and borehole observatory data from subduction zones throughout the globe indicate that the shallow portion of the subduction zone may accumulate and release strain through a variety of deformation mechanisms (seismogenic slip, creep, slow slip, tremor) over a range of timescales (seconds, weeks, months, years; Peng and Gomberg, 2010).

The Core-Log-Seismic Integration at Sea (CLSI@Sea) workshop was held from 12 January to 7 February 2018 onboard D/V Chikyu in the Nankai Trough subduction zone, off southwestern Japan. This workshop was developed to enhance multidisciplinary research to address the role of accretionary prism frontal deformation in tsunamigenic earthquakes and slow slip in the shallow portion of the subduction interface. A singular aspect of CLSI@Sea lay in the fact that it was designed to leverage existing archives of IODP cores and logging data and associated seismic datasets previously acquired as part of the Nankai Trough Seismogenic Zone Experiment (NanTroSEIZE) program. Recent findings from the 2011 Tohoku-Oki mega earthquake in the Japan Trench indeed provided evidence that tsunamigenic slips can be continuous from the locked portion of the subduction plate boundary all the way out to the trench (Chester et al., 2013). Similar behavior has been previously documented in the shallow portion of the Nankai subduction zone (Kinoshita et al., 2009; Sakaguchi et al., 2011; Ito et al., 2013), within the NanTroSEIZE study area, thus highlighting the interest in re-investigating archived NanTroSEIZE data to characterize the nature of fault slip and strain accumulation, fault architecture, and state variables throughout subduction plate boundary systems.

The CLSI@Sea workshop represented an original approach in several aspects. First, CLSI@Sea was an unprecedented opportunity to examine legacy data from multiple former expeditions in the context of a mission not dedicated to core recovery. CLSI@ Sea workshop was the first of its kind organized concurrently with an International Ocean
Drilling Program (IODP) expedition. Expedition 380 installed a long-term borehole monitoring system (LTBMS) at Site C0006, above the deformation front of the Nankai accretionary prism, thus allowing workshop participants to investigate archived data from the site where the IODP expedition was focused and interact with the expedition science party. Second, a challenging aspect of the workshop was to connect a group of science mentors with extensive experience in the Nankai margin with early-career researchers from diverse research backgrounds (Table 1), to work on common research questions. Third, workshop participants were given the opportunity to pursue new research while onboard Chikyu, thanks to full access to shipboard laboratory facilities to re-investigate the IODP archived data. Well-preserved sedimentary cores were brought onboard Chikyu from the Kochi Core Center and made available for laboratory analyses. Seismic reflection, log, and drilling parameter data were also kindly provided to all workshop participants onboard.

The international team of workshop participants was then able to develop interdisciplinary discussions and organize both individual and collaborative research plans to address outstanding questions regarding seismogenic-, tsunamigenic- and slow-slip processes in the Nankai subduction zone, a crucial topic for the regional tectonics, but also a fundamental aspect of the Earth's geodynamics.

\section{Background and geological setting}

The Nankai Trough is formed by the subduction of the Philippine Sea Plate beneath the Eurasian Plate, forming the Nankai prism by the accretion of the Shikoku Basin oceanic plate sediments (Fig. 1). The complex geodynamic evolution of the Shikoku Basin, including the migration of the boundaries of the Amurian, Pacific and Philippine plates over time (e.g., Moore et al., 2015), has resulted in large lateral variations in basement relief, with associated variations in the nature and thickness of sediments, resulting in structures highly variable laterally within the accretionary prism (Fig. 1). In cross section (Fig. 2), the deformation front is located at the toe of the prism, at the boundary with the deepest part of the trough. Upslope from the prism toe (Fig. 2), several landward-dipping imbricated thrusts and associated anticlines and back-thrusting branches form together the Im- 
Table 1. CLSI@Sea participants, D/V Chikyu, IODP 380, Nankai Trough, 12 January-7 February 2018.

\begin{tabular}{|c|c|c|c|}
\hline Name & Speciality & Institution & Email \\
\hline Anna Cerchiari & Structural geology & Univ. of Modena (It.) & anna.cerchiari@gmail.com \\
\hline Rina Fukuchi & Sedimentology, structural geology & JAMSTEC (Jap.) & rfukuchi@jamstec.go.jp \\
\hline Baiyuan Gao & Geomechanics, physical properties & Univ. of Texas (USA) & baiyuan@utexas.edu \\
\hline Kan-Hsi Hsiung & Sedimentology, structural geology & JAMSTEC (Jap.) & hsiung@jamstec.go.jp \\
\hline Dominik Jaeger & Lithostratigraphy, sedimentology & Univ. of Innsbruck (AUT) & Fabian.Jaeger@student.uibk.ac.at \\
\hline Shunya Kaneki & Geochemistry, physical properties & Osaka Univ. (Jap.) & skaneki@ess.sci.osaka-u.ac.jp \\
\hline Jonas Keller & Lithostratigraphy, sedimentology & Univ. of Innsbruck (AUT) & Jonas.Keller@student.uibk.ac.at \\
\hline Szu-Ting Kuo & Geomechanics, physical properties & Texas A\&M Univ. (USA) & teddythebest@tamu.edu \\
\hline Gaël Lymer & Geophysics, structural geology & Univ. of Birmingham (UK) & g.lymer@bham.ac.uk \\
\hline Tatiana Maison & Sedimentology, structural geology & UniLaSalle (Fr.) & Tatiana.Maison@unilasalle.fr \\
\hline Ginta Motohashi & Physical properties & Univ. of Tsukuba (Jap.) & ginta_m@geol.tsukuba.ac.jp \\
\hline Christine Regalla & Structural geology & Boston Univ. (USA) & cregalla@bu.edu \\
\hline Drake Singleton & Geophysics, sedimentology & San Diego Univ. (USA) & dsinglet@ucsd.edu \\
\hline Suguru Yabe & Geophysics, seismology & JAMSTEC (Jap.) & syabe@jamstec.go.jp \\
\hline \multicolumn{4}{|l|}{ CLSI@Sea mentors } \\
\hline Keir Becker & IODP Exp. 380 Co-Chief & Univ. of Miami (USA) & k.becker@miami.edu \\
\hline Kyuichi Kanagawa & Structural geology & Chiba Univ. (Jap.) & kyu_kanagawa@faculty.chiba-u.jp \\
\hline Gaku Kimura & Structural geology & $\begin{array}{l}\text { Tokyo Univ. of Marine } \\
\text { Science and Technology }\end{array}$ & gkimur0@kaiyodai.ac.jp \\
\hline Masa Kinoshita & IODP Exp. 380 Co-Chief & Univ. Of Tokyo & masa@eri.u-tokyo.ac.jp \\
\hline Gregory Moore & Geophysics & Univ. of Hawaii (USA) & gmoore@hawaii.edu \\
\hline Demian Saffer & Physical properties & Penn. State Univ. (USA) & dms45@psu.edu \\
\hline Michael Strasser & Sedimentology & Univ. of Innsbruck (AUT) & Michael.Strasser@uibk.ac.at \\
\hline Kiyoshi Suyehiro & Seismology & JAMSTEC (Jap.) & suyehiro@jamstec.go.jp \\
\hline Michael Underwood & Lithostratigraphy & Univ. Missouri (USA) & underwoodm@missouri.edu \\
\hline \multicolumn{4}{|l|}{ Staff scientists } \\
\hline Yukari Kido & Logging scientist & JAMSTEC (Jap.) & ykido@jamstec.go.jp \\
\hline Lena Maeda & Lab manager & JAMSTEC (Jap.) & maedal@jamstec.go.jp \\
\hline Yoshinori Sanada & Logging scientist & JAMSTEC (Jap.) & sanada@jamstec.go.jp \\
\hline Sean Toczko & IODP Exp. 380 project manager & JAMSTEC (Jap.) & sean@jamstec.go.jp \\
\hline
\end{tabular}

bricate Thrust Zone (ITZ; Park et al., 2002; Moore et al., 2009). The thrusts of the ITZ sole into the basal décollement, corresponding to a strong continuous positive polarity reflection on the seismic reflection data. A potential inactive décollement occurs $\sim 500 \mathrm{~m}$ above the active one in a zone of the low P-wave velocity zone that may correspond to underplated hemipelagic material (Kamei et al., 2012). Beneath the upper slope, two distinctive branches of a first-order thrust correspond to the Mega-Splay Fault (MF; Park et al., 2002, 2010). The MF cuts across the older part of the accretionary prism and can be traced deep $(\sim 10 \mathrm{~km})$ toward the top of the subducting plate (Fig. 2). The MF extends more than $120 \mathrm{~km}$ along strike (Fig. 1; Moore et al., 2007; Park et al., 2010) and is strongly suspected to be one of the primary coseismic faults that may have contributed to generating devastating historic earthquakes and tsunamis (Tanioka and Satake, 2001; Kikuchi et al., 2003; Wang and Hu, 2006). Landward of the MF, the oldest parts of the prism are overlain by marine sediments accumulated in the Kumano forearc basin, bounded to the southeast by a topographic valley at the limit between the basin and the upper part of the trench slope (Fig. 2). This valley corresponds to the Kumano Basin edge fault zone (KBEFZ) that may have a combination of normal and strike-slip faults (Martin et al., 2010).

The Nankai subduction zone has a 1300-year historical record of recurring tsunamigenic earthquakes, including the 1944 Tonankai $M_{\mathrm{w}} 8.2$ and 1946 Nankai $M_{\mathrm{w}} 8.3$ earthquakes (Fig. 1), and has been the focus of worldwide marine scientific surveys, including the NanTroSEIZE drilling program. NanTroSEIZE focuses on the Kumano transect of the Nankai accretionary prism (Fig. 2). To date, the program has involved 11 oceanic expeditions, 13 sites of coring and logging, collection of 2-D and 3-D seismic data, and installation of a network of LTBMS' recording in situ data within the Nankai accretionary prism. Collectively, these data provide an unprecedented record of the margin's stratigraphic and structural evolution. Within the NanTroSEIZE study area, Sites C0006 and C0007 (IODP Expeditions 314 and 316; 


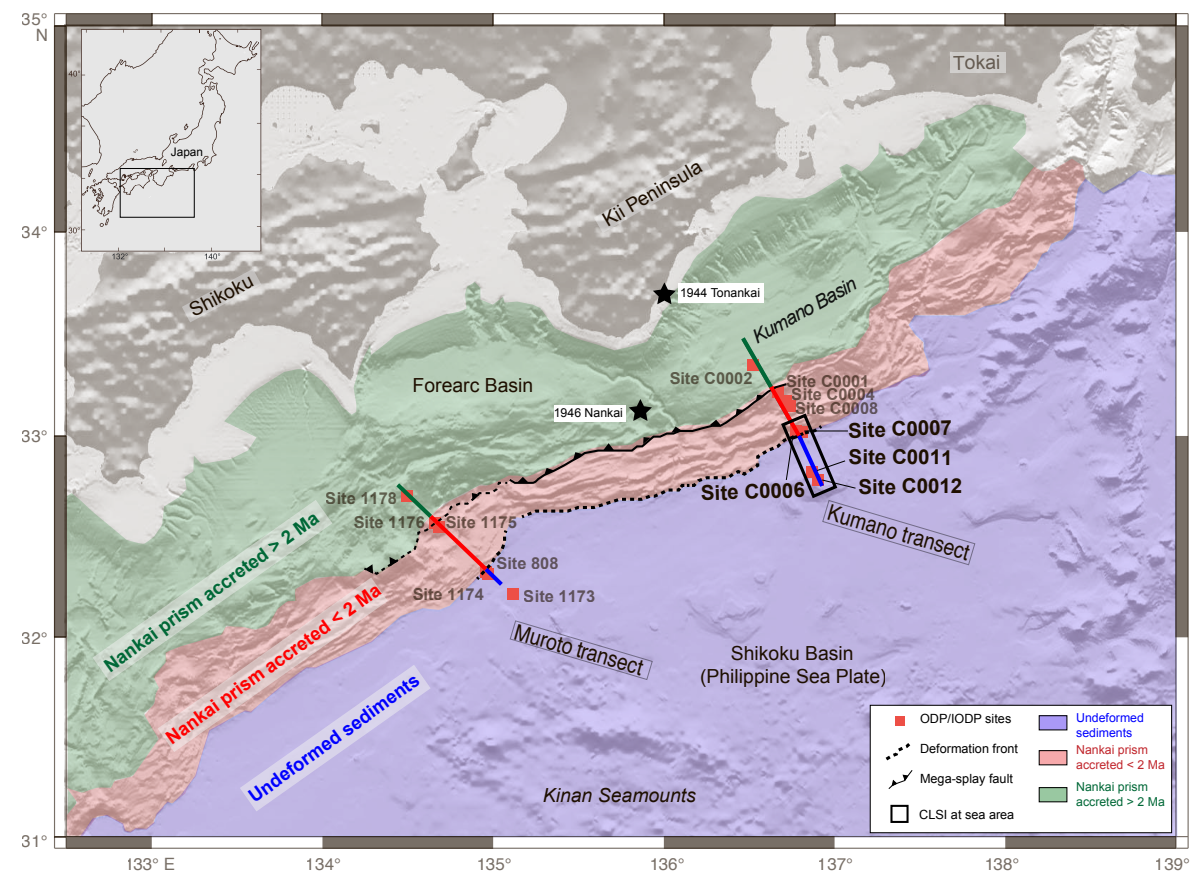

Figure 1. Synthesis map of the Nankai Trough offshore southwestern Japan. The area of investigation of the CLSI@ Sea workshop corresponds to the black frame, including Site C0006, the target of IODP Expedition 380. The colors show the stage of evolution of the deformation within the Nankai Trough. The two sections across the Kumano and Muroto transects are shown in Fig. 2. Compiled and modified from Kimura et al. (2014) and Moore et al. (2001, 2009).

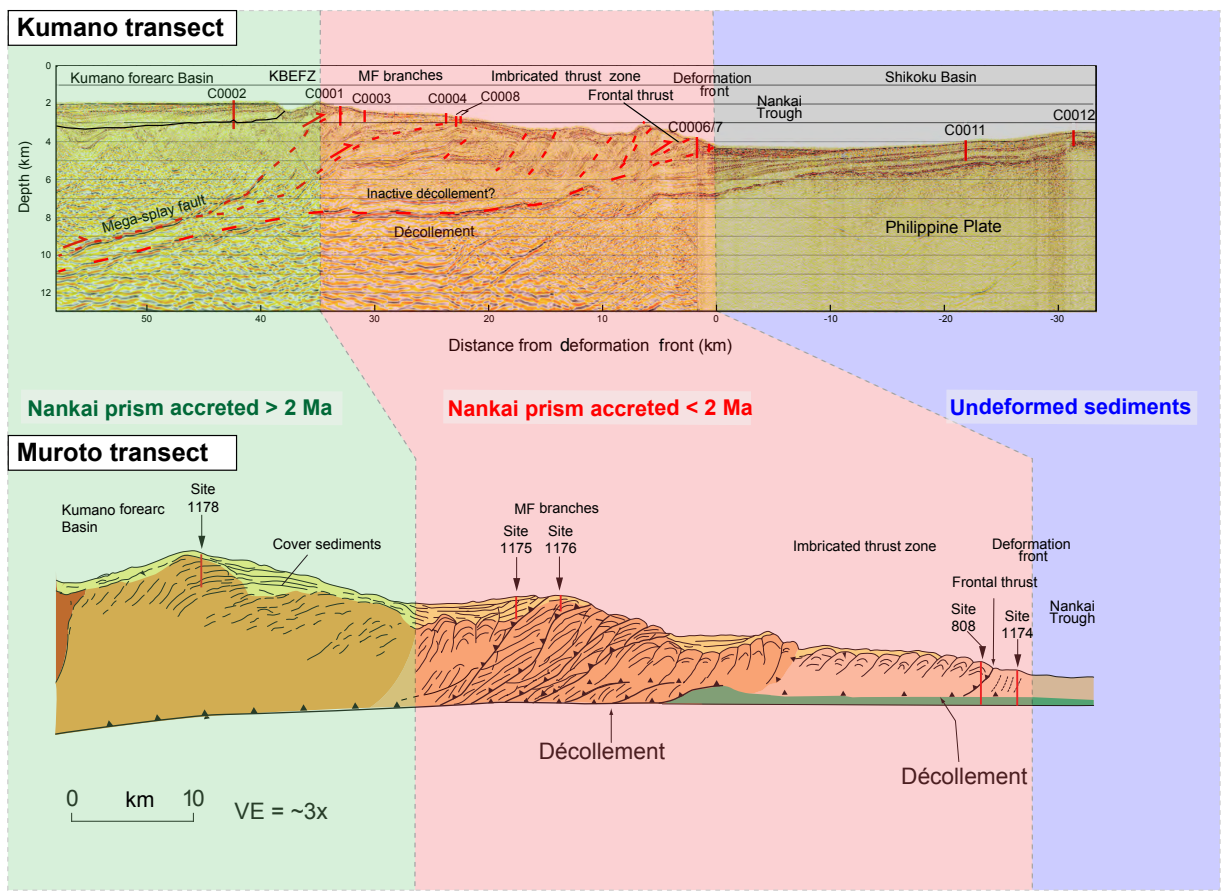

Figure 2. Synthesis structural cross sections across the Nankai accretionary prism along the Kumano and Muroto transects. See location in Fig. 1. The colors are the same as Fig. 1 and refer to the stage of evolution of the deformation within the Nankai Trough, namely, blue: non-accreted sediments; red: accreted sediments less than 2 My ago; green: accreted sediments more than 2 My ago. Modified from Moore et al. (2001) and (2009). 
Kimura et al., 2008; Kinoshita et al., 2008 and 2009) located at the deformation front of the Nankai accretionary prism (Fig. 1), and Sites C0011 and C0012 (IODP Expeditions 322, 333, and 338; Underwood et al., 2010; Henry et al., 2011; Strasser et al., 2014), located oceanward of the deformation front, were key targets for the CLSI@ Sea workshop to investigate the most recent deformations within the prism toe. In addition, Site C0006 is considered to be outside of the major earthquakes' nucleation zone (Hyndman and Wang, 1993; Oleskevich et al., 1999). However, normal and slow earthquakes (low-frequency tremors, very low-frequency earthquakes, and slow slip events) all seem to possibly occur inside the core sample zone of Sites C0006 and C0007. The installation of the LTBMS during Expedition 380 provides the opportunity to collect data to facilitate understanding of how the seismic slips are controlled at this particular zone of the deformation front, possibly one of the most studied areas on Earth in the quest to better understand tsunamigenic earthquake processes. Equally, the purpose of the CLSI@Sea program is to enhance understanding of this area by re-visiting previously acquired data and core material from the region.

\section{Workshop organization}

The CLSI@Sea workshop brought together a team of international scientists, mentors and early-career researchers (Table 1) to address outstanding questions on tsunamigenic earthquake processes at plate subduction zones, specifically investigating the Nankai Trough (Fig. 1). A fundamental characteristic of the workshop was the multi-disciplinary expertise of the participants, selected on the basis of their research proposals aiming to investigate different aspects of subduction mechanisms and related processes. Scientific self-introductions during the first days of the workshop were essential to identify the research interests of each participant (Table 1) and develop collaborative research plans based on multi-disciplinary teamwork. Scientific talks given by the mentors and IODP Expedition 380 Co-Chiefs (Table 1) provided an overview of the geological processes identified over the last 10 years at the Nankai subduction zone, at different levels and at different scales of the NanTroSEIZE area, from the seafloor to the top of the subducting plate. Presentations by both mentors and workshop participants helped to trigger discussions and facilitate knowledge transfer between groups, which represented crucial points to identify the key research questions and develop both individual and collaborative research strategies.

Workshop participants developed efficient selforganization, supported by personal initiatives contributing to the CLSI@Sea community research objectives. The participant group self-organized, supported by individual research plans that had been proposed to contribute to the CLSI@Sea program research objectives. As is always the case with highly multi-disciplinary collaborative projects such as IODP, a degree of flexibility and compromise was also required, with initial research plans being modified and adjusted to avoid duplication of effort and to ensure the best fit with the over-arching program objectives. In parallel to personal research plans, group research was undertaken by small teams of participants focused on generating a comprehensive synthesis of previous Nankai Trough research arising from IODP expeditions (see Sect. 4), to help identify any outstanding scientific questions. In addition, this collaborative work extended to the development of a database of the scientific literature generated by previous NanTroSEIZE projects and the submission of this workshop report to promote the international, multi-disciplinary CLSI@Sea initiative.

Personal research projects centred on the analysis of the seismic reflection data, logging data and sedimentary cores from Site C0006 (Holes C, D, E, F), Site C0007 (Holes A, B, C, D) and Site C0012 (Hole A) (see Fig. 1 for location). In particular, Sites C0006 and C0007 provided the opportunity to examine cores from the Pliocene and Miocene sections down to the décollement (Figs. 4 and 5) at the deformation front. In line with IODP protocols, sample requests had to be submitted and approval received prior to any sampling and analysis of the core material. Software and data handling training was also provided by laboratory technicians to participants to improve efficiency in executing their research projects while onboard Chikyu. These individual and collaborative efforts were supported by daily meetings in which the mentoring team provided workshop participants with input and guidance for their ongoing work. The research projects undertaken by the participants included (Sects. 4 and 5) investigations on an accurate age model for the accretionary prism's frontal thrust development; seafloor/sub-bottom morphological response to subduction along the Nankai Trough; P-wave velocity-porosity relationship in the deformation front area; and multi-dimensional analysis of plate boundary faults.

Finally, CLSI@Sea participants were invited to closely follow the progress of Expedition 380, especially in terms of drilling processes and day-to-day technical challenges occurring during IODP expeditions.

\section{Integration of legacy IODP data}

The coordination of the synthesis of previous IODP NanTroSEIZE projects made to facilitate the organization of future individual and collaborative research plans resulted in the formation of research teams focused on three main subtopics: lithostratigraphy, tectonic structures of the Nankai prism and physical properties of the deformation front. The goal of these research teams was to build a compilation of the formerly published results in the different sub-topics, and across the different IODP sites investigated during this workshop. This compilation was a fundamental aspect of the 


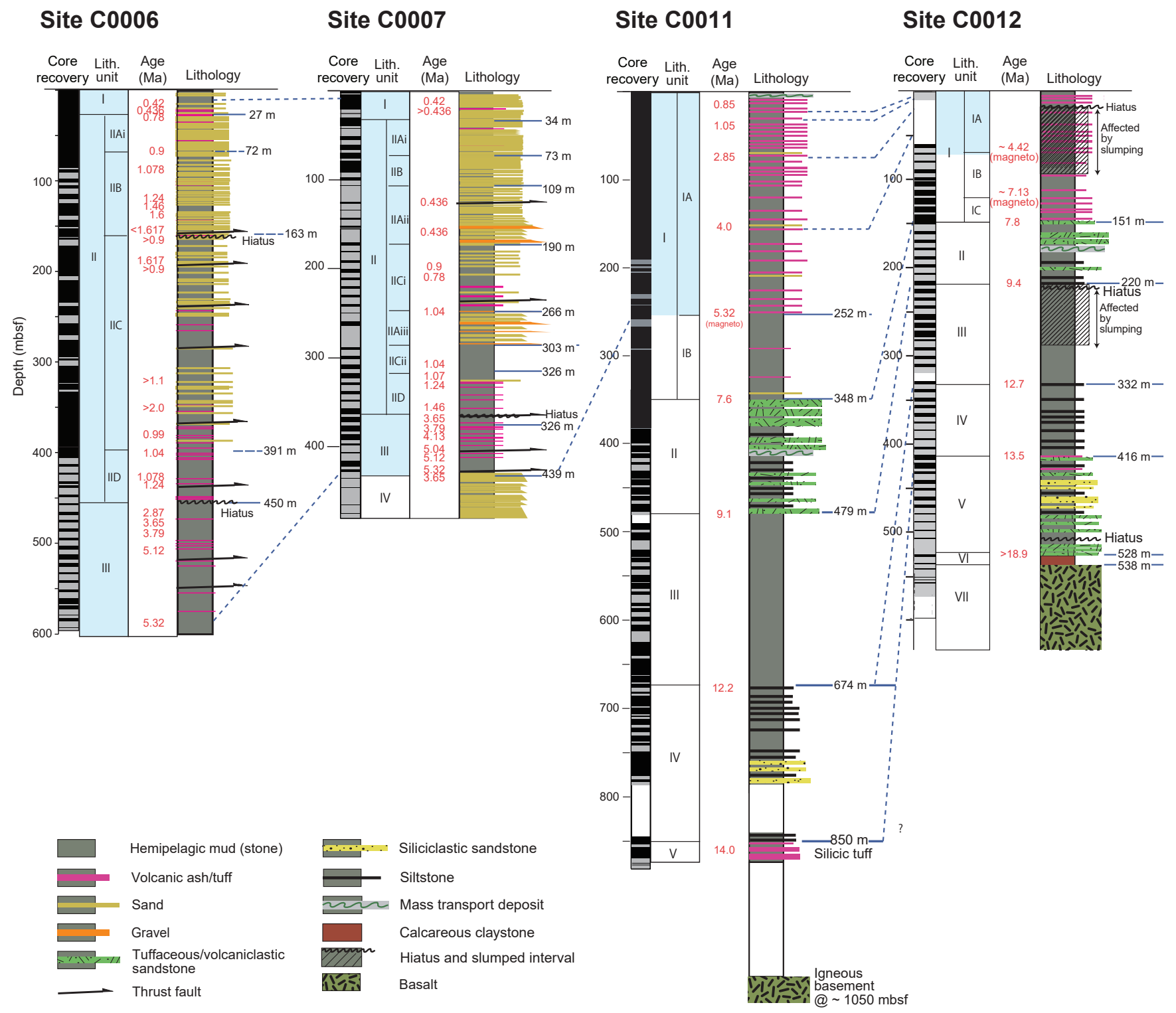

Figure 3. Lithological section across the Nankai frontal prism (Sites C0006 and C0007) and the input sites (C0011 and C0012). The columns at each site show core recovery, lithologic units, sedimentary age, and lithology distribution modified from Kinoshita et al. (2009), Strasser et al. (2014), and references therein.

workshop, to create a state-of-the-art of the existing results and bring up new scientific questions, but also to set up a dynamic work collaboration between the participants.

\subsection{Lithostratigraphy of the frontal prism and incoming sediments}

The workshop resulted in a new synthesis of the lithostratigraphy and chronostratigraphy for reference Sites C0011 and C0012 and frontal thrust zone Sites C0006 and C0007 (Fig. 3). Reconstruction of the regional sedimentation history and the plate boundary evolution was considered through lithological and stratigraphic analysis of core and data from the incoming Philippine Sea Plate. The original intent of coring ahead of the prism (Sites C0011 and C0012, Fig. 1) was to provide a largely undisturbed record of input sediment cover that could be used to decipher the timing of the formation of the structures at the deformation front (Sites C0006 and C0007, Underwood et al., 2010; Henry et al., 2011; Strasser et al., 2014). The onset of deformation was identified based on the lateral changes in thickness of the upper wedge deposits (lithologic Units I and II in C0006 and C0007, Fig. 3), a key target for scientific questions. During CLSI@Sea, the temporal resolution of stratigraphic units was investigated, and the efficiency of new crystallographic 
analytical tools to better understand accretionary wedge deformation evolution was tested. Below we briefly summarize the correlated stratigraphy at each site and variations in bulk mineralogical content.

Sites C0011 and C0012 transect the entire incoming sediment sequence of the Shikoku Basin to basaltic ocean crust (Fig. 3) (Underwood et al., 2010; Strasser et al., 2014). Unit I corresponds to late Pleistocene to late Miocene Upper Shikoku Basin deposits, and contains silty clay with minor ash. Unit II is marked by the occurrence of volcaniclastic sandstones in silty claystone and corresponds to late Miocene Middle Shikoku Basin deposits. Units III to V correspond to late to middle Miocene Lower Shikoku Basin deposits. Unit III is a succession of uniform silty claystone and lime mudstone; Unit IV contains silty claystone/clayey siltstone comprising fine-grained, turbiditic sand layers; Unit V contains tuffaceous sandy siltstone with some silty claystone and tuff. The oldest units recovered include calcareous mudstone (Unit IV) overlying oceanic basement basalts (Unit VII). The dominant mineral assemblages are quartz, feldspar, clay minerals and calcite. No major trends in mineral content are observed within Units I and V, but Unit VI has an overall higher clay content and lower quartz and feldspar contents compared to overlying units.

Sites C0006 and C0007 transect accreted Shikoku basin deposits and overlying wedge slope deposits (Kinoshita et al., 2009). Unit I contains unconsolidated hemipelagic mud and turbidites deposited in a wedge slope environment ( $\mathrm{Ki}$ noshita et al., 2009). Unit II contains alternating sequences of Pleistocene hemipelagic muds and turbidites deposited in a transitional trench-wedge environment. Unit II, which directly overlies the décollement at Sites C0006 and C0007, is made up of accreted sediments correlated with the Pliocene to Upper Miocene in the Shikoku Basin. Unit IV, recovered below the décollement at Site C0007, consists of a small $(\sim 15 \mathrm{~cm})$ section of dark, medium to coarse-grained sands. As in Site C0012, the dominant mineral assemblage is feldspar, clay minerals and calcite, and does not display major trends in mineral content.

New investigation and sampling of the sedimentary cores from Sites C0006, C0007 and C0012 during the CLSI@Sea workshop involve the following methods: new tephrachronology/geochronology, clay mineral composition analysis, and macroscopic and XCT re-observation of sedimentary structure. These methods will provide data that will help address the following outstanding questions.

- What is the provenance of accretionary prism body, slope, and fault sediments? How well can we correlate incoming Shikoku basin stratigraphy with off scraped sediments in the frontal prism?

- Is it possible to link the origin of the Nankai prism sediments with the migration of the Philippine Sea-Pacific plate boundary over the Miocene to the present?
- How well can we reconstruct the development and the evolution of the prism from the tectono-stratigraphic framework of the Kumano Basin?

\subsection{Tectonic structure of the frontal thrust}

The workshop results in a new synthesis of structural features observed in core, log, and seismic data from the incoming plate and frontal wedge of the Nankai prism, including identification of new faulted intervals in the formal prism. The structures of the Nankai prism at the deformation front, where the thrust-fault activity is the youngest (Fig. 1) and the compressional deformation propagates oceanward (Moore et al., 2009; Underwood and Moore, 2012), were examined. Proposed research projects arising from CLSI@Sea and focusing on the structures of the subduction zone included scientific questions related to the timing, amplitude and mechanisms of fault slips, the relationships between deformations and shallow sedimentary processes and their link with potentially tsunamigenic events, especially earthquakes and generation of mass transport deposits. Specifically, the integration and compilation of structural and lithologic data (Fig. 4) across multiple IODP reports and publications allow for the refinement of the presence, extent, and slip history of faults at the deformation front of the prism. Below we briefly summarize structural data from core and log data at Sites C0012, C0006 and C0007 before discussing new observations made during the workshop.

Site C0012 is located seaward of the deformation front. Bedding orientations at this site are dominantly subhorizontal, with intervals of higher angle bedding resulting from gravitational slumping, and high angle fractures resulting from subvertical compaction. Sites C0006 and C0007 penetrated the first two imbricate thrusts at the deformation front, including the main frontal thrust at $\sim 700 \mathrm{~m}$ LWD depth below seafloor (LSF) (Figs. 2, 3 and 5; Kinoshita et al., 2008, 2009). Bedding at Site C0007 is dominantly subhorizontal, but a major lithologic inversion at $\sim 400-450 \mathrm{~m}$ b.s.f. places moderately consolidated hemipelagic mudstones over poorly consolidated trench turbidite sands. Site C0006 can be divided into four log units corresponding to distinct structural domains (Fig. 4). Unit I (0-100 m LSF) has generally westdipping bedding resulting from northwestward tilting driven by plate convergence and southwestward tilting driven by gravitational slumping. Unit II (100-220 m LSF) is a thrust zone that contains several faults identified in core, log and seismic data (Fig. 5). Units III and IV (below $220 \mathrm{mLSF}$ ) contain northwestward-dipping beds and fractures, consistent with north-northwestward-directed shortening driven by plate convergence.

In addition to previously reported faults, workshop work resulted in the observation of new faults correlated thanks to the integration of core, $\log$ and seismic data (blue strips in Fig. 4). Cores from Sites C0006 and C0007 intersect several major faults, including the plate boundary interface in- 


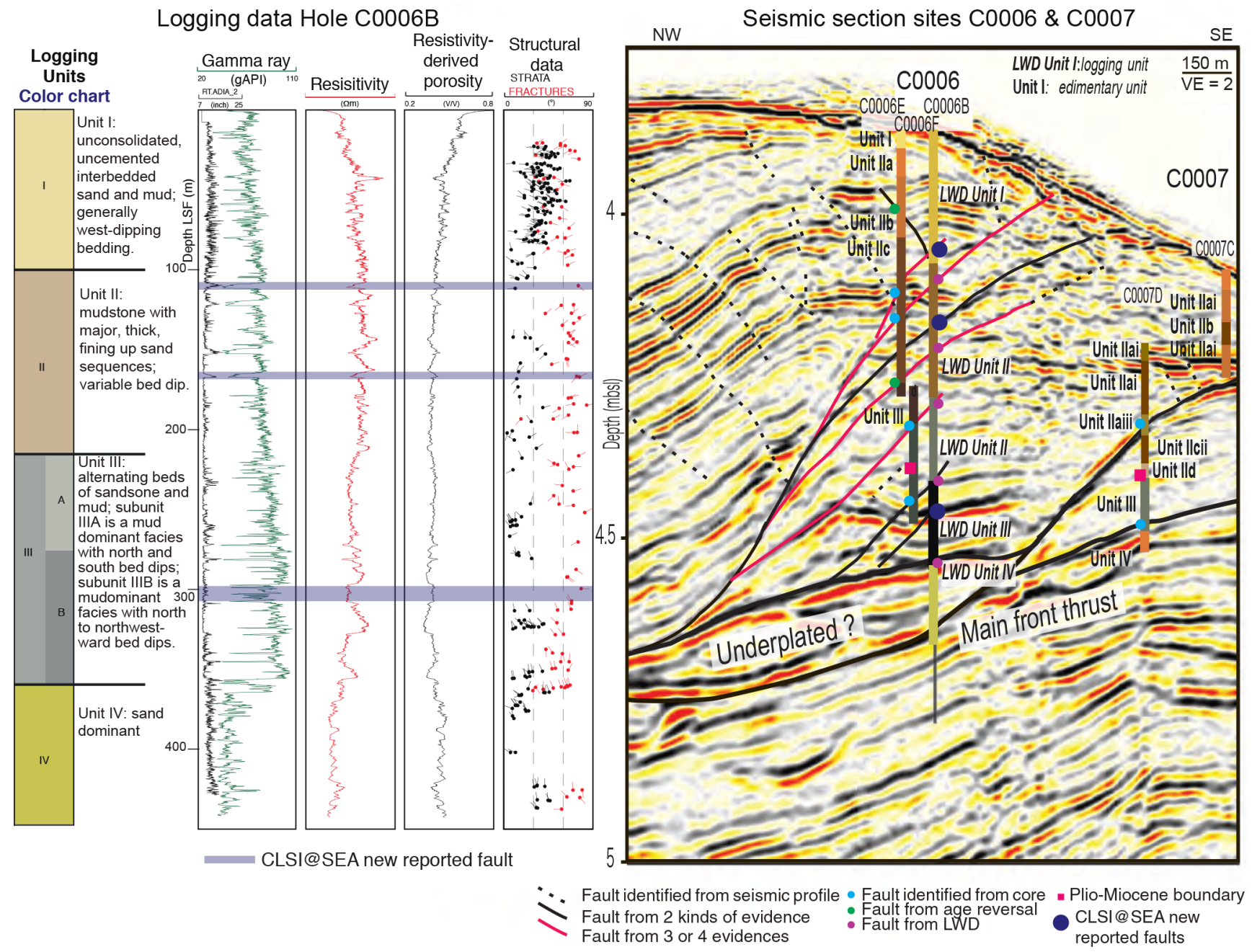

Figure 4. Sedimentary, logging and seismic data at the deformation front of the Nankai prism (Sites C0006 and C0007). Dark blue markers (strips, dots) are additions provided by the CLSI@Sea workshop. The figure shows (from left to right) the logging data at Hole C0006B, the interpreted seismic section (IL 2435) across the Nankai 3-D volume illustrating the structures at the deformation front, and the lithological units and the logging units identified at both Sites $\mathrm{C} 0006$ and C0007. Some structures (dark blue) have been identified by integration of the Core-Logging-Seismic data. Figure compiled and modified from Kimura et al. (2008) and Kinoshita et al. (2008, 2009).

tersected at Site C0006 at $\sim 700 \mathrm{mLSF}$ and Site C0007 at $\sim 400 \mathrm{~m}$ LSF (Kinoshita et al., 2008, 2009). In the cores, faults largely occur as breccias, gouges, and zones with striated fractures, in which the sense of displacement is often difficult to observe directly. A black gouge-bearing fault zone recovered in the core from Site C0007 at $438 \mathrm{mLSF}$ exhibits a vitrinite reflectance anomaly interpreted to reflect shear heating during past seismic slip to the trench (Sakaguchi et al., 2011). In log data, faults can be identified by simultaneous decreasing of the gamma ray and resistivity values. Cross-comparison of core and log data with 3-D seismic reflection data across the Kumano transect allowed observation of the persistent lateral continuity of the main thrusts across the seismic volume, whereas secondary and tertiary branches of the thrusts show important lateral variations in three dimensions.

Continued structural analysis of the site $\mathrm{C0006}$ and $\mathrm{C} 0007$ data involving resistivity $\log$ fracture analysis, thin section observations, high-resolution CT scans, re-interpretation of the NanTroSEIZE 3-D volume and geochemical analysis across fault zones will be used to address the following questions.

- What is the temporal history of slip along frontal prism faults? Which sedimentary horizons are offset by thrusts? Do any thrusts breach the seafloor?

- Which structural features exist in the region where seismic tremors have been identified, and which may be genetically linked to tremorgenic processes? 


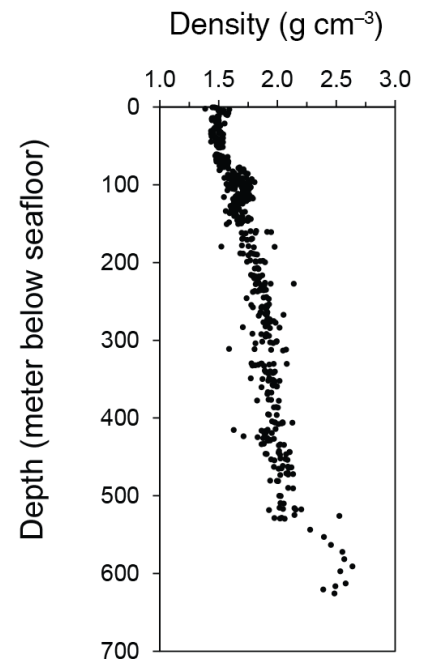

(a)

$$
\text { CT number }
$$

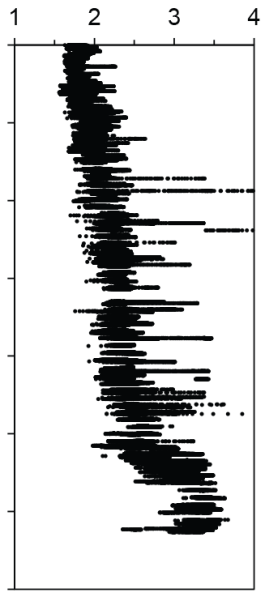

(b)

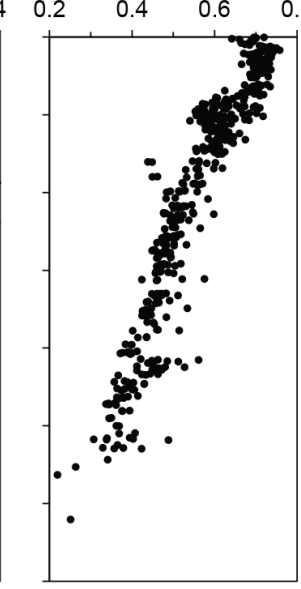

(c)
Vp $\left(\mathrm{m} \mathrm{s}^{-1}\right)$

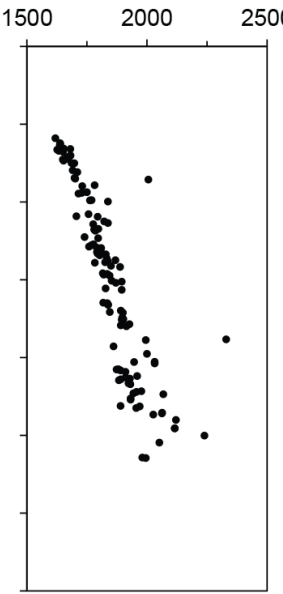

(d)
$\operatorname{ROP}\left(\mathrm{m} \mathrm{h}^{-1}\right)$

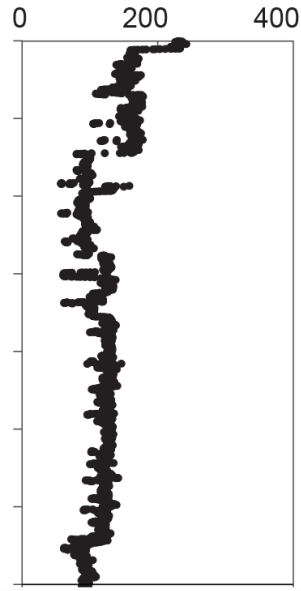

(e) (f)

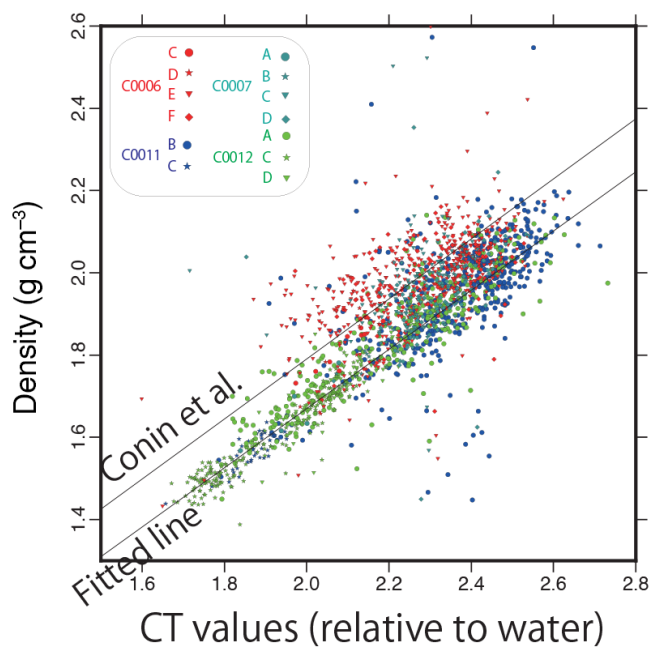

(g)

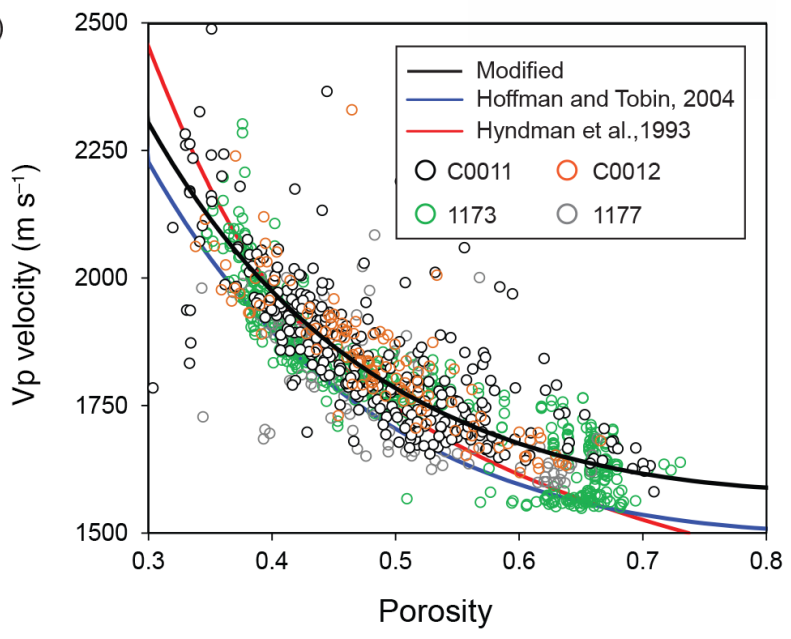

Figure 5. (a-e) Density, CT number, porosity, P-wave velocity $\left(V_{\mathrm{P}}\right)$, and rate of penetration (ROP) along depth at Site C0012. Density, porosity and $V_{\mathrm{P}}$ data are from discrete samples of Holes C0012A, C0012C, and C0012G. ROP is measured at Holes C0012B and C0012H. CT measurements on cores are from Holes C0012A, C, D, E, F, and G. (f) The correlation between CT value and density value at C0006, C0007, C0011, and C0012. (g) The correlation of porosity and $V_{\mathrm{P}}$ at Sites C0011, C0012, 1173, and 1177.

- What are the distribution, origin and timing of the mass transport deposits along the Kumano transect and are they temporally linked with fault activity?

- What is the 3-D architecture of the prism? How strong are the lateral variations of the structures within the prism?

\subsection{Physical properties in the frontal thrust and incoming plate}

The workshop also led to new compilations and analysis of $\log$, computed tomography (CT), and rate of penetration (ROP) data that will promote research on the physi- cal properties (PPs) of the sedimentary units and faults recovered from the cores. These include establishing a relationship between the $\mathrm{P}$-wave velocity $\left(V_{\mathrm{P}}\right)$ and the porosity within the sedimentary layers; mapping the physical properties within the prism; estimating stress within the prism; quantifying the frictional heat generated during fault slips, particularly at the décollement; investigation of the slip properties along the faults in order to understand the slip behavior from temperatures; and mapping the porosity distribution. PPs of drilled cores are measured onboard Chikyu using a Multi-Sensor Core Logger (MSCL) system, discrete-sample measurements, and CT images. Each of these measurements has limitations and was not previously well integrated. For 
example, the MSCL system can measure PPs of intact and split cores non-destructively, but the measurement is sometimes scattered if the recovered cores are fractured. PPs can also be measured precisely using discrete samples; however, the results from discrete samples are conducted intermittently and only represent a portion of the recovered cores. Concerning CT images, they are taken as a first step before core splitting and are thus able to reveal the continuous internal structure of a drilled core without any destruction. Such images therefore represent a high potential for future studies investigating, e.g., 3-D PPs distributions or fracture mechanics considering small-scale structure around the fault. Compilation and integration of various types of data including CT scan analysis can then provide continuous and more accurate PPs for whole drilled cores. Below we summarize new synthesis and analyses completed during the CLSI@Sea workshop.

Investigations on PPs included analysis on density, porosity, and compressional P-wave velocity of the incoming plate sites (Sites C0011 and C0012, Fig. 1) and the frontal thrust sites (Sites C0006 and C0007). CT values are converted into density using the following equation (Kinoshita et al., 2009):

CTvalue $=\frac{f_{\text {material }}-f_{\text {water }}}{f_{\text {water }}} \times 1000$,

where $f_{\text {water }}$ and $f_{\text {material }}$ are, respectively, the linear attenuation coefficients of water and the measured material. The attenuation coefficient is a function of the chemical composition and the density of the material. We find that the relation between CT value and density for input sites (C0011 and C0012) lies well on a straight line (Fig. 5), but there is a slight difference from the relation obtained for sites in the accretionary prism (Conin et al., 2014). Although the dependency on lithology and chemical compositions has been investigated in relation to onboard visual core descriptions and X-ray fluorescence analysis, the cause has not been clarified yet. The porosity-depth and porosity- $V_{\mathrm{P}}$ relationships in the outboard Sites C0011 and C0012 follow a similar trend to site 1173 (Muroto transect, Fig. 1). Hoffman and Tobin (2004) have shown an empirical relationship of porosity and $V_{\mathrm{P}}$ based on the Muroto transect. Here we incorporate the NanTroSEIZE data (C0011, C0012) and define a modified empirical relationship based on Hoffman and Tobin (2004) (Fig. 5). C0006 and C0007 have limited and scattered discrete core data; thus, they are not included to constrain the porosity $-V_{\mathrm{P}}$ trend.

ROP is one of the key parameters to assess the drilling efficiency and can be used to estimate the sliding friction coefficient (Pessier and Fear, 1992). We compile ROP at Sites $\mathrm{C} 0006 \mathrm{~B}$ and $\mathrm{C} 0012 \mathrm{H}$ where drilling parameters are available and compare the trend to the core-scale physical properties. The first $100 \mathrm{~m}$ of a dataset may not be appropriate for further calculation as there is obvious fluctuation. Future work includes investigation of the impacts of different drilling meth- ods and comparison of the mechanical properties of different lithological units.

The spatial distribution of PPs (especially porosity) contains key information of the degree of compaction and stress states around faults and décollement. As an example of CLSI@Sea using compiled PPs, we estimated the porosity distribution along the NanTroSEIZE transect. The $V_{\mathrm{P}}$ dataset (Moore et al., 2007; Park et al., 2010) covers the locations from the inner wedge (near Site C0009) to the deformation front (Sites C0006 and C0007) and to the seaward sites (C0011, C0012). We are then able to apply the empirical $V_{\mathrm{P}}$-porosity relationship to estimate the porosity distribution. From the preliminary results, we clearly see that there is a high-porosity zone along the décollement associated with the low-velocity zone (Park et al., 2010). This high-porosity zone indicates under-compaction and may suggest high excess pressure during tectonic loading. Future work will include (i) mapping the porosity distribution more precisely by integrating the data in the inner wedge (e.g., Site C0002, Fig. 1), and (ii) estimating the stress and pressure state using the improved porosity distribution results.

Additional post-cruise research involving data compilation, consolidation tests, frictional heating experiments, refinements to velocity structure models and log-seismic correlations will be used to address the following research questions.

- What is the ancient and modern thermal state in the frontal prism, and how is it modified by frictional heating and fluid flows?

- What is the porosity and pore fluid pressure evolution in the accretionary prism, basal décollement, and underthrust sediments?

- What are the roles of faults and fractures in fluid circulation within the frontal prism and deformation zones?

\section{New findings and opportunities}

\subsection{Core-log-seismic integration at the deformation front of the Nankai accretionary prism}

One of the main objectives of the CLSI@Sea workshop was to provide participants with the opportunity to undertake research based on legacy IODP data acquired in the frontal thrust (Fig. 1, Sites C0006, Holes C, D, E, F, and C0007, Holes A, B, C, D) and outboard regions (Site C0012, Hole A) of the Nankai prism. Through individual and collaborative research, CLSI@Sea participants conducted preliminary analysis during the workshop, using integration of core, logging and seismic data. The cores were brought onboard Chikyu for the workshop and made available for sampling, allowing the participants to obtain a total of 519 core samples to analyze the lithological properties, micro-fabrics, grain size distribution, and fracture characteristics. 


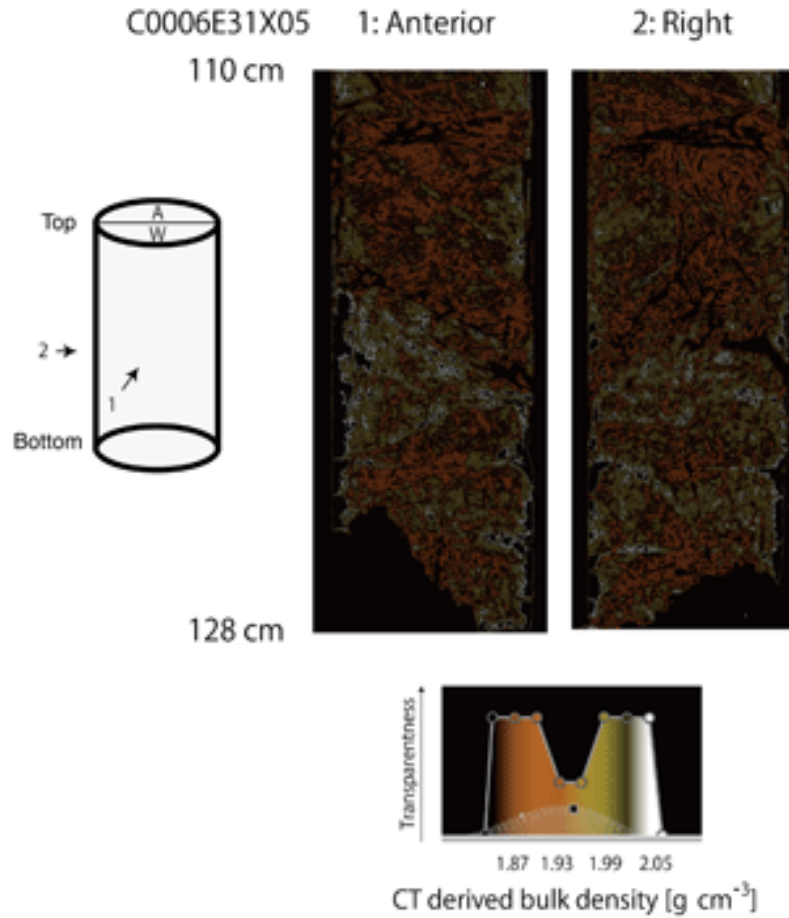

Figure 6. Bulk density distributions converted from the CT value for section C0006E31X05 110-128 cm. Two cross sections through the centre of the core are presented. A 3-D distribution of this section is presented as a movie in the Supplement.

An example of core-log-seismic integration concerns investigations of the fault zone at Site C0006 (Fig. 4). Although several fault zones are reported in the expedition reports of this site (see Sect. 4, Kimura et al., 2008, and Kinoshita et al., 2008, for more details), studies of fault zones so far have mainly concentrated on the Mega-Splay Fault (Fig. 1) and the toe of the décollement (Site C0007, Fig. 4). As a first step of the investigation, seismic reflection data have been checked to identify major fault zones with sufficient displacement. The depths of identified faults have then been estimated by studying the logging resistivity images and core CT images. Based on the estimation of the depth of the faults, stored cores have been thoroughly observed, allowing identification of several faults, which were consequently sampled for further analysis.

During CLSI@Sea, we recognized the importance of quantitatively integrating CT images into other data; $\mathrm{CT}$ values are indeed meaningful since they reflect the physical and chemical properties of the material as addressed in Sect. 4.3. Despite the great non-destructive advantage of CT images, only a few studies have used the information of CT values in the NanTroSEIZE project so far (e.g., Conin et al., 2014). Figure 6 (and the Supplement) shows the 3-D bulk-density distribution of one identified fault with a proper color scale, which is usually with grey scale in the original CT images (see Fig. 24 of the expedition report by Kinoshita et al.,
2009). A 3-D image of CT-value-derived bulk density with millimeter-scale resolution was thus very powerful in identifying potential faults.

\subsection{Post-cruise studies}

The time spent onboard Chikyu during IODP Expedition 380 was the first step of a longer-term renewal of the NanTroSEIZE research program resulting from the CLSI@Sea workshop investigations. Once back in their home institutions (Table 1), CLSI@Sea participants will make progress with their individual and collaborative research projects that were initiated onboard Chikyu. The targets of these studies fall into three main scientific fields: (i) lithology and stratigraphy (paleo-temperature, frontal prism and incoming plate stratigraphy, turbidites, sedimentary flow paths, and clay minerals); (ii) tectonic structures (along- and across-strike geometry of thrusts, faults and relationship with the décollement and shallow sedimentary processes, age and evolution of the deformation, and fracture distribution); (iii) physical properties (porosity, stress, heat, shear deformation, P-wave velocity, friction, fault slip behavior, and sedimentary consolidation). The future laboratory analysis and experiments on the sedimentary cores sampled onboard Chikyu will include optical microscope observation, scanning electron microscope (SEM) observation, energy-dispersive X-ray spectroscopy (EDS), X-ray diffraction (XRD) analysis, X-ray CT, triaxial tests, friction experiments, radiogenic decay, and vitrinite reflectance measurements. The logging, seismic reflection, and velocity data will be analyzed using geophysical interpretation tools, and will eventually be correlated with the new results. The successful installation of the LTBMS on Site C0006 during Expedition 380 will also provide additional in situ data for NanTroSEIZE investigators, including real-time pressure, strain, and seismological data. Connection of the Site C0006 LTBMS to the Dense Oceanfloor Network System for Earthquakes and Tsunamis (DONET) cabled network managed by the Japanese Agency for MarineEarth Science and Technology (JAMSTEC) will allow provision of crucial day-to-day global records of the Nankai prism activity to understand the evolution of the subduction zone.

Discussing all together the different open targets raised within each research sub-group, workshop participants agreed that their correlation of former results (Sect. 4) and future analysis would allow them to answer key questions that can be summarized as follows.

- What governs subduction zone seismogenic fault locking vs. stable-slip and/or transitional fault behavior? Is there an "updip limit" to the seismogenic zone, and what controls its spatio-temporal evolution? What governs tsunami generation characteristics for a given great earthquake?

- What are the geologic, physical, and chemical signatures of slow slip, tremor, and seismogenesis? What 
are the deformation mechanisms recorded in the frontal prism and how do the length scales and timescales of their formation relate to the observed length scales and timescales of strain accumulation and release?

- Does fault state evolve during interseismic and preseismic periods? If so, how?

- What do fault zone structure and compositions reveal about slip mechanisms in tsunamigenic frontal ramp thrusts? What are the implications of variable properties for the fault zones and their architecture, evolution, and slip behavior?

- What are the geomechanical, frictional and physical properties of the fault zones and wall rock in the overriding and subducted plate? How do these rock properties vary spatially in the volume of rock away from the borehole, as sampled by 3-D seismic data? How are these properties related to the in situ stress state and strain accumulation?

- What is the ancient and modern thermal state in the frontal prism, and how is it modified by frictional heating and fluid flow?

- What is the porosity and pore fluid pressure evolution in the accretionary prism, basal décollement, and under thrust sediments? What are the roles of faults and fractures in fluid circulation within the frontal prism and deformation zones?

- What are the distribution, origin and timing of mass transport deposits and how may these relate to past seismogenic (tsunamigenic) slip, eustacy, and climatic variations?

- What is the sediment provenance of Nankai sediments? What can this tell us about forearc evolution and plate boundary migration over the Miocene to present?

- What is the sequence stratigraphic and tectonostratigraphic framework of the Kumano basin and forearc? What is the relationship between basin development, uplift, eustasy, or tectonism in the accretionary wedge and trench?

- What is the 3-D spatio-temporal evolution of accretion and fault slip in the frontal prism? How do the timing and rate of slip on prism faults relate to seismogenesis? How does prism evolution respond to changing subduction parameters?

The CLSI@Sea workshop has demonstrated the value of re-investigating archive data. The results arising from postcruise research undertaken by the participants has the potential to further improve our understanding of the Nankai Trough and subduction processes.

\subsection{Lessons learned and suggestions for future workshops}

The CLSI@Sea workshop was the first of its kind to run alongside an IODP expedition. The initiative was motivated by a need to re-investigate legacy data, and to bring "new eyes" to the NanTroSEIZE program. Some suggestions arising from this new initiative were the following.

- Multi-disciplinary collaboration. One of the keys in the efficacy and the success of the CLSI@Sea workshop was the multi-disciplinarity of the participant pool (Table 1), resulting in a complementary approach to the scientific questions, which demonstrates the value of group collaboration in tandem with individual research projects. Results from studying the evolution of the Nankai Trough highlighted the multi-parameter factors of the complex processes occurring at this plate boundary, and the necessity to address subduction and earthquake mechanisms with multiple methodologies that integrate across different scales of space and time. Similar initiatives on specific research thematics or regional problematics, including data and core material from former IODP expeditions, could represent an efficient mechanism by which research value could be added to the IODP legacy.

- Communication and focussing. Connecting specialist mentors and early-career scientists from different backgrounds successfully resulted in a transfer of knowledge between both parties. Lively discussions in a cordial atmosphere and teamwork between mentors, participants and IODP staff in the Chikyu focused environment were key components in the development of scientific questions and efficient formulation of both individual and collective research plans. Face-to-face (or "face-to-direct-live-screen") interactions during talks given by the mentors were crucial to confirm the current state-of-the-art and to avoid duplication of efforts. Self-introduction of workshop participants was also a fundamental point to highlight individual research interests and build research teams and collaborations. Pre-workshop communication (mentors-participants, participants-participants, collection of publications and list of available data during the workshop) represents efficiency in identification of research interests, organization of collaborations, and improvement of individual knowledge and research strategy.

- Data availability and sampling. Training on data analytical techniques, school sampling and software support provided by scientific staff was crucial to facilitate access to and work on the data. During CLSI@Sea, workshop participants had the opportunity to access public data (IODP archives) and restricted data (3-D seismic reflection data) kindly provided for investigations. A 
major issue concerning the archived sedimentary cores is the limited amount of data due to the nature of the cores themselves, by definition limited in terms of quantity of available material. Thus, complete missing sections of cores previously already sampled (fault planes particularly) represented important issues to the participants aiming to analyze the sedimentary records of the deformation, as well as for future researchers interested in investigating sedimentary archives theoretically available for the entire scientific community. This issue could be resolved at long term with the development of non-destructive analysis, such as X-ray CT (see Sects. 4.3 and 5.1).

- Motivation and self-organization. The motivation, initiative, and self-organization of the workshop participants were essential keys to the program's success. Most of the ideas on the organization of the research aspect of the workshop (see Sect. 3) came from the participants, who were free to organize their research and expose their ideas to the other participants, supported by the staff scientists and the mentors. This freedom allowed the ideas to arise easily from the discussion sessions and individual thinking, and were a fundamental aspect of the success of the CLSI@Sea workshop.

\section{Summary}

The Nankai Trough is one of the most active plate margins of the planet, and one of the most studied, being the focus of many IODP expeditions and related surveys that collectively acquired a huge quantity of data over the last decades, thus being a key area for the understanding of tsunamigenic earthquakes. The CLSI@Sea workshop demonstrated the value of revisiting IODP archives and integration of different types of data, core, logging and seismic, providing indications of several processes acting on different scales. The success and the productivity of CLSI@Sea thus demonstrated the interest in organizing such a workshop for any scientific discipline. The workshop participants formulated scientific questions to better understand the sedimentary, structural and physical aspects of subduction processes. Analyses initiated onboard Chikyu are now continuing at participants' home institutions, following the research plans elaborated during the workshop.CLSI@Sea participants plan to meet in the year following the workshop, in order to discuss and correlate their results, confident that international collaboration will lead to high-impact outcomes in the global understanding of inter-disciplinary processes in subduction zones.

Data availability. All the data used during this workshop and presented in this report are archived IODP data and therefore publicly accessible, or accessible on request, from the IODP website (https: //www.iodp.org/resources/access-data-and-samples, IODP Science support office, 2018).

\section{Information about the Supplement}

Supplementary movie. Three-dimensional distributions of bulk density converted from the CT value presented in Fig. 6 . In Supplement movies, the same section (C0006E31X05 $110-128 \mathrm{~cm}$ ) is rotated horizontally. The color scale is the same as the one presented in Fig. 6 .

Supplement. The supplement related to this article is available online at: https://doi.org/10.5194/sd-24-93-2018-supplement.

Author contributions. RF, BG, GL, TM, CR and SY were the main contributors to this report. All authors participated in the discussions, data synthesis and writing. GL suggested writing and publishing this report and coordinated the writing work during and after the expedition.

Competing interests. The authors declare that they have no conflict of interest.

Acknowledgements. We thank IODP, CDEX, JAMSTEC, MWJ, and MQJ for generously providing logistical and financial support for the CLSI@Sea workshop and event attendees. We thank all the mentors for their support, their availability resulting in constructive discussions during the workshop. A special mention is for Gaku Kimura, at the origin of the idea of this workshop. We acknowledge the staff from JAMSTEC, Sean Tockzo, Lena Maeda, Yukari Kido, and Yoshinori Sanada, for the logistic organization of the workshop and their valuable advice onboard Chikyu. We also thank the Expedition 380 science party for their good mood and their availability to discuss and present their tasks, despite the incredible amount of work they had to manage. The whole crew and staff of D/V Chikyu, from the sailors to the stewards, the kitchen staff and the laboratory staff, and all the other teams we cannot list here, deserve special thanks for their hospitality and for doing a superb job, taking care of the workshop participants, and providing them with a fantastic environment to focus only on scientific questions. Finally, thanks go to all workshop attendees and participating scientists for their motivation and enthusiastic contributions, during and after the event, thereby helping to develop this report as a first concrete outcome from the CLSI@Sea workshop.

All investigators, workshop attendees, the Exp. 380 Science party and daily reports can be found on the NanTroSEIZE Expedition 380 project website at https: //www.jamstec.go.jp/chikyu/e/nantroseize/expedition_380.html (last access: 22 September 2018).

Edited by: Ulrich Harms

Reviewed by: Sally Morgan, Michael Riedel, and one anonymous referee 


\section{References}

Chester, F. M., Mori, J., Eguchi, N., Toczko, S., and the Expedition 343/343T Scientists: Proceedings of the Integrated Ocean Drilling Program, 343/343T: Tokyo (Integrated Ocean Drilling Program Management International, Inc.), https://doi.org/10.2204/iodp.proc.343343T.2013, 2013.

Conin, M., Bourlange, S., Henry, P., Boiselet, A., and Gaillot, P.: Distribution of resistive and conductive structures in Nankai accretionary wedge reveals contrasting stress paths, Tectonophysics, 611, 181-191, https://doi.org/10.1016/j.tecto.2013.11.025, 2014.

Henry, P., Kanamatsu, T., and the Expedition 333 Scientists: NanTroSEIZE Stage 2: Nantrosliz. Leg 333 Expedition Reports, Proceedings of the Integrated Ocean Drilling Program, vol. 333, Tokyo, 2011.

Hoffman, N. W. and Tobin, H. J.: An empirical relationship between velocity and porosity for underthrust sediments in the nankai trough accretionary prism, in: Proceedings of the Ocean Drilling Program, Scientific Results, edited by: Mikada, H., Moore, G. F., Taira, A., Becker, K., Moore, J. C., and Klaus, A., 190/196, 1-23, 2004.

Hyndman, R. and Wang, K.: Thermal constraints on the zone of major thrust earthquake failure: The Cascadia subduction zone, J. Geophys. Res.-Sol. Ea., 98, 2039-2060, 1993.

Hyndman, R. D., Moore, G. F., and Moran, K.: Velocity, porosity, and pore-fluid loss from the Nankai subduction zone accretionary prism, in: Proc. ODP, Sci. Results, 131: College Station, TX (Ocean Drilling Program), edited by: Hill, I. A., Taira, A., Firth, J. V., and Vrolijk, P. J., 211-220, 1993.

IODP Science support office: IODP Access Data and Samples, https://www.iodp.org/resources/access-data-and-samples, last access: 22 September 2018.

Ito, Y., Hino, R., Kido, M., Fujimoto, H., Osada, Y., Inazu, D., Ohta, Y., Iinuma, T., Ohzono, M., Miura, S., Mishina, M., Suzuki, K., Tsuji, T., and Ashi, J.: Episodic slow slip events in the Japan subduction zone before the 2011 Tohoku-Oki earthquake, Tectonophysics, 600, 14-26, https://doi.org/10.1016/j.tecto.2012.08.022, 2013.

Kamei, R., Pratt, R. G., and Tsuji, T.: Waveform tomography imaging of a megasplay fault system in the seismogenic Nankai subduction zone, Earth Planet. Sc. Lett., 317-318, 343-353, https://doi.org/10.1016/j.epsl.2011.10.042, 2012.

Kikuchi, M., Nakamura, M., and Yoshikawa, K.: Source rupture processes of the 1944 Tonankai earthquake and the 1945 Mikawa earthquake derived from low-gain seismograms, Earth Planets Space, 55, 159-172, 2003.

Kimura, G., Screaton, E. J., Curewitz, D., and the Expedition 316 Scientists: NanTroSEIZE Stage 1A: NanTroSEIZE shallow megasplay and frontal thrusts, IODP Prel. Rept., 316, https://doi.org/10.2204/iodp.pr.316.2008, 2008.

Kimura, G., Hashimoto, Y., Kitamura, Y., Yamaguchi, A., and Koge, H.: Middle Miocene swift migration of the TTT triple junction and rapid crustal growth in southwest Japan: A review, Tectonics, 33, 1219-1238, https://doi.org/10.1002/2014TC003531, 2014.

Kinoshita, M., Tobin, H., Moe, K. T., and the Expedition 314 Scientists: NanTroSEIZE Stage 1A: NanTroSEIZE LWD transect,
IODP Prel. Rept., 314, https://doi.org/10.2204/iodp.pr.314.2008, 2008.

Kinoshita, M., Tobin, H., Ashi, J., Kimura, G., Lallemant, S., Screaton, E. J., Curewitz, D., Masago, H., Moe, K. T., and the Expedition 314/315/316 Scientists: Proceedings of the Integrated Ocean Drilling Program, 5, 314/315/316: Washington, DC (Integrated Ocean Drilling Program Management International, Inc.), https://doi.org/10.2204/iodp.proc.314315316.2009, 2009.

Lay, T., Kanamori, H., Ammon, C. J., Nettles, M., Ward, S. N., Aster, R. C., Beck, S. L., Bilek, S. L., Brudzinski, M. R., Butler, R., DeShon, H. R., Ekström, G., Satake, K., and Sipkin, S.: The great Sumatra-Andaman earthquake of 26 December 2004, Science, 308, 1127-1133, https://doi.org/10.1126/science.1112250, 2005.

Martin, K. M., Gulick, S. P. S., Bangs, N. L. B., Moore, G. F., Ashi, J., Park, J. O., Kuramoto, S., and Taira, A.: Possible strain partitioning structure between the Kumano fore-arc basin and the slope of the Nankai Trough accretionary prism, Geochem. Geophy. Geosy., 11, Q0AD02, https://doi.org/10.1029/2009GC002668, 2010.

Moore, G. F., Taira, A., Klaus, A., Becker, L., Boecker, B., Cragg, B. A., Dean, A., Fergusson, C. L., Henry, P., Hirano, S., Hisamitsu, T., Hunze, S., Kastner, M., Maltman, A. J., Morgan, J. K., Murakami, Y., Saffer, D. M., Sanchez-Gomez, M., Screaton, E. J., Smith, D. C., Spivack, A. J., Steurer, J., Tobin, H. J., Ujiie, K., Underwood, M. B., and Wilson, M.: New insights into deformation and fluid flow processes in the Nankai Trough accretionary prism: Results of Ocean Drilling Program Leg 190, Geochem. Geophy. Geosy., 2, 22 pp., https://doi.org/10.1029/2001GC000166, 2001.

Moore, G. F., Bangs, N. L., Taira, A., Kuramoto, S., Pangborn, E., and Tobin, H. J.: Three-dimensional splay fault geometry and implications for tsunami generation, Science, 318, 1128-1131, 2007.

Moore, G. F., Park, J.-O., Bangs, N. L., Gulick, S. P., Tobin, H. J., Nakamura, Y., Sato, S., Tsuji, T., Yoro, T., Tanaka, H., Uraki, S., Kido, Y., Sanada, Y., Kuramoto, S., and Taira, A.: Structural and seismic stratigraphic framework of the NanTroSEIZE Stage 1 transect, in: Proc. IODP, 314/315/316: Washington DC (Integrated Ocean drilling Program Management International, Inc.), edited by: Kinoshita, M., Tobin, H., Ashi, J., Kimura, G., Lallement, S., Screaton, E. J., Curewitz, D., Masago, H., Moe, K. T., and the Expedition 314/315/316 Scientists, https://doi.org/10.2204/iodp.proc.314315316.102.2009, 2009.

Moore, G. F., Boston, B. B., Strasser, M., Underwood, M. B., and Ratliff, R. A.: Evolution of tectono-sedimentary systems in the Kumano Basin, Nankai Trough forearc, Mar. Petrol. Geol., 67, 604-616, https://doi.org/10.1016/j.marpetgeo.2015.05.032, 2015.

Moreno, M., Rosenau, M., and Oncken, O.: 2010 Maule earthquake slip correlates with pre-seismic locking of Andean subduction zone, Nature, 467, 198-202, https://doi.org/10.1038/nature09349, 2010.

Oleskevich, D., Hyndman, R., and Wang, K.: The updip and downdip limits to great subduction earthquakes: Thermal and structural models of Cascadia, south Alaska, SW Japan, and Chile, J. Geophys. Res.-Sol. Ea., 104, 14965-14991, 1999. 
Park, J.-O., Tsuru, T., Kodaira, S., Cummins, P. R., and Kaneda, Y.: Splay Fault Branching Along the Nankai Subduction Zone, Science, 297, 1157-1160, 2002.

Park, J.-O., Fujie, G., Wijerathne, L., Hori, T., Kodaira, S., Fukao, Y., Moore, G. F., Bangs, N. L., Kuramoto, S., and Taira, A.: A low-velocity zone with weak reflectivity along the Nankai subduction zone, Geology, 38, 283-286, 2010.

Peng, Z. and Gomberg, J.: An integrated perspective of the continuum between earthquakes and slow-slip phenomena, Nat. Geosci., 3, 599-607, 2010.

Pessier, R. C. and Fear, M. J.: Quantifying Common Drilling Problems with Mechanical Specific Energy and a Bit-Specific Coefficient of Sliding Friction, Society of Petroleum Engineers, 2, 373-388, https://doi.org/10.2118/24584-MS, 1992.

Sakaguchi, A., Chester, F., Curewitz, D., Fabbri, O., Goldsby, D., Kimura, G., Li, C.-F., Masaki, Y., Screaton, E. J., Tsutsumi, A., Ujiie, K., and Yamaguchi, A.: Seismic slip propagation to the updip end of plate boundary subduction interface faults: Vitrinite reflectance geothermometry on Integrated Ocean Drilling Program NanTroSEIZE cores, Geology, 39, 395-398, https://doi.org/10.1130/G31642.1, 2011.

Simons, M., Minson, S. E., Sladen, A., Ortega, F., Jiang, J., Owen, S. E., Meng, L., Ampuero, J.-P., Wei, S., Chu, R., Helmberger, D. V., Kanamori, H., Hetland, E., Moore, A. W., and Webb, F. H.: The 2011 magnitude 9.0 Tohoku-Oki earthquake: mosaicking the megathrust from seconds to centuries, Science, 332, 1421-1425, https://doi.org/10.1126/science.1206731, 2011.

Strasser, M., Dugan, B., Kanagawa, K., Moore, G. F., Toczko, S., Maeda, L., Kido, Y., Moe, K. T., Sanada, Y., Esteban, L., Fabbri, O., Geersen, J., Hammerschmidt, S., Hayashi, H., Heirman, K., Hüpers, A., Jurado Rodriguez, M. J., Kameo, K., Kanamatsu, T., Kitajima, H., Masuda, H., Milliken, K., Mishra, R., Motoyama, I., Olcott, K., Oohashi, K., Pickering, K. T., Ramirez, S. G., Rashid, H., Sawyer, D., Schleicher, A., Shan, Y., Skarbek, R., Song, I., Takeshita, T., Toki, T., Tudge, J., Webb, S., Wilson, D. J., Wu, H.-Y., and Yamaguchi, A.: Expedition 338 summary, in: Proceedings of the Integrated Ocean Drilling Program, Volume 338: Yokohama, Japan, Integrated Ocean Drilling Program, edited by: Strasser, M., Dugan, B., Kanagawa, K., Moore, G. F., Toczko, S., and Maeda, L., 47 pp., https://doi.org/10.2204/iodp.proc.338.101.2014, 2014.
Tanioka, Y. and Satake, K.: Detailed coseismic slip distribution of the 1944 Tonankai earthquake estimated from tsunami waveforms, Geophys. Res. Lett., 28, 1075-1078, 2001.

Underwood, M. B. and Moore, G. F.: Evolution of sedimentary environments in the subduction zone of southwest Japan: recent results from the NanTroSEIZE Kumano transect. Tectonics of Sedimentary Basins: Recent Advances, Chapter 15, 310-326, First Edition, edited by: Busby, C. and Azor, A., Blackwell Publishing Ltd., 2012.

Underwood, M. B., Saito, S., Kubo, Y., and the Expedition 322 Scientists: Expedition 322 summary, in: Proc. IODP, 322. Tokyo, Integrated Ocean Drilling Program Management International, Inc., edited by: Saito, S., Underwood, M. B., Kubo, Y., and the Expedition 322 Scientists, https://doi.org/10.2204/iodp.proc.322.101.2010, 2010.

Wang, K. and Hu, Y.: Accretionary prisms in subduction earthquake cycles: The theory of dynamic Coulomb wedge, J. Geophys. Res., 111, B06410, https://doi.org/10.1029/2005JB004094, 2006. 